\title{
The Influence of Electrical Current Density and Type of the External Source of Carbon on Nitrogen and Phosphorus Efficiency Removal in the Sequencing Batch Biofilm Reactor
}

\author{
Izabella Kłodowska', Joanna Rodziewicz' ${ }^{1 *}$, Wojciech Janczukowicz' \\ 1 University of Warmia and Mazury in Olsztyn, Faculty of Environmental Sciences, Department of Environment \\ Engineering, Warszawska 117a, 10-719 Olsztyn, Poland \\ * Corresponding author's e-mail: joanna.rodziewicz@uwm.edu.pl
}

\begin{abstract}
This work presents the results of a study on the effect of electrical current density $\left(53,105,158\right.$ and $\left.210 \mathrm{~mA} / \mathrm{m}^{2}\right)$, type of the external source of carbon (citric acid, potassium bicarbonate), and $\mathrm{C} / \mathrm{N}_{\mathrm{NO} 3}$ ratio $(0.5,1.0$ and 1.5) on the effectiveness of nitrogen and phosphorus removal from synthetic wastewater with physicochemical parameters typical of municipal sewage subjected to bio-treatment in the highly efficient system for organic compounds removal ensuring efficient course of the nitrification process. The denitrification efficiency was found to depend on the type and dose of carbon and on the electrical current density. Higher values of this parameter were determined in the reactor with citric acid than in one with potassium bicarbonate used as carbon sources. Total phosphorus was removed in the processes of electrocoagulation and biomass growth. Higher efficiency of dephosphatation was achieved in the reactor with electrical current passage than in the reactor without it. The type of carbon source had little effect on the dephosphatation efficiency. The use of electrical current density of $210 \mathrm{~mA} / \mathrm{m}^{2}$ and citric acid as a carbon source with $\mathrm{C} / \mathrm{N}=1.5$ allowed achieving $87.61( \pm 1.6) \%$ efficiency of denitrification and $97.69( \pm 2.1) \%$ efficiency of dephosphatation.
\end{abstract}

Keywords: bio-electrochemical reactor, external source of carbon, citric acid, potassium bicarbonate, denitrification, dephosphatation

\section{INTRODUCTION}

The discharge of wastewater containing biogenic substances to natural waters contributes to an excessive growth of algae, which leads to the eutrophication of water bodies and affects the quality of drinking water resources. Nitrates constitute a major source of contaminants in the underground and surface waters, and their presence in drinking water poses risk to the human health and to other living organisms [Carrera et al., 2004; Lee et al., 2006]. Low effectiveness of conventional methods for water and wastewater treatment has recently led to the development of novel technologies for the removal of biogenic substances. These compounds may be neutralized in biological and physicochemical processes. The biological processes are cost-effective, relatively easy to conduct, highly stable and reliable, but more time-consuming and slower compared to the physicochemical methods [Hiscock et al., 1991; Ghafari et al., 2008]. Therefore, attempts are undertaken to intensify the processes of biological denitrification through ensuring better contact between microorganisms and nitrates. These attempts are mainly focused on the systems with a biofilm which are convenient for denitrification owing to their cohesiveness. Compared to the reactors with suspended sludge and fluidized beds, the reactors with a solid filling are characterized by a greater simplicity of handling, lower volume, lesser sludge production, higher stability and resistance to a shock load [Zhu and Chen, 2002].

Electrical current passage through a sequencing batch reactor with a biofilm immobilized on a carrier in the form of disks (SBBR) enables 
coupling the processes of biological and physicochemical treatment. In a reactor of this type, the nitrogen compounds will be removed primarily in the process of autotrophic (hydrogenotrophic) denitrification, whereas the phosphorus compounds - in the process of coagulation [Kłodowska et al., 2013]. Research works mainly provide the results from the experiments conducted in the systems with separate various reactors for denitrification and electrocoagulation processes [Karanasios et al., 2010; Feng et al., 2013; Shalaby et al., 2014; Kuokkanen et al., 2015].

The authors of this manuscript have demonstrated in their earlier works the feasibility of using an SBBR type bio-electrochemical reactor for the treatment of wastewater with high concentrations of nitrates and phosphorus and with low concentrations of organic compounds at selected densities of electrical current and unitary doses of organic and inorganic substrates [Kłodowska et al., 2013; Kłodowska et al., 2014; Kłodowska et al., 2016].

The presented study was aimed at determining the effect of electrical current density, type of carbon source and $\mathrm{C} / \mathrm{N}_{\mathrm{NO} 3}$ ratio on the efficiency of nitrogen and phosphorus compounds removal in the bio-electrochemical SBBR from the wastewater with physicochemical parameters typical of municipal sewage subjected to prior bio-treatment in the system, enabling highly efficient removal of organic compounds and highly efficient nitrification.

\section{METHODS}

The experiments were conducted simultaneously in vertical sequencing batch biofilm reactors (SBBR) with the volume of $3.0 \mathrm{~L}$ each (active volume $-2.0 \mathrm{~L}$ ), under anaerobic conditions. A set of 12 disks made of stainless steel with the diameter of $0.10 \mathrm{~m}$ and total surface of $0.19 \mathrm{~m}^{2}$ was mounted in each reactor. The distance between disks was $5 \mathrm{~mm}$. They were mounted coaxially on a vertical shaft rotating with the speed of $10 \mathrm{rpm}$; their submersion rate was $100 \%$ (Fig. 1).

The experiment was conducted under the following conditions: without the passage of electrical current (reactors: $\mathrm{R}_{0}, \mathrm{R}_{\mathrm{CA}}$ and $\mathrm{R}_{\mathrm{PB}}$ ), and with the passage of electrical current (reactors: $\mathrm{R}_{\mathrm{H} 2}$, $\mathrm{R}_{\mathrm{CA}+\mathrm{H} 2}$ and $\left.\mathrm{R}_{\mathrm{PB}+\mathrm{H} 2}\right)$. In the control reactor $\left(\mathrm{R}_{0}\right)$, without electrical current flow and without external source of carbon, the synthetic wastewater was subjected to bio-treatment. In another two reactors $\left(\mathrm{R}_{\mathrm{CA}}\right.$ and $\left.\mathrm{R}_{\mathrm{PB}}\right)$ without electrical current flow, citric acid and potassium bicarbonate, respectively, were used in the concentrations ensuring the $\mathrm{C} / \mathrm{N}_{\mathrm{NO} 3}$ ratios of $0.5,1.0$ and 1.5 . In the reactors with the passage of electrical current, no external source of carbon was introduced in the reactor $\mathrm{R}_{\mathrm{H} 2}$ or in $\mathrm{R}_{0}$, whereas citric acid and potassium bicarbonate were fed as carbon sources to the reactors $\mathrm{R}_{\mathrm{CA}+\mathrm{H} 2}$ and $\mathrm{R}_{\mathrm{PB}+\mathrm{H} 2}$, respectively. Wastewater retention time was 24 hours in each reactor. The carbon dose applied ensured the $\mathrm{C} / \mathrm{N}_{\mathrm{NO} 3}$ ratio of $0.5,1.0$ and 1.5 in wastewater fed to reactors. When computing the doses of organic and inorganic carbon, consideration was given to the carbon concentration in crude wastewater after dissolution of enriched broth. The broth was added to wastewater to achieve a desired COD value being typical of the municipal sewage treated in the system intended for the aerobic biological removal of organic compounds and for nitrification (e.g. in four-stage biological disk contactor). In the reactors without the external substrate $\left(\mathrm{R}_{0}\right.$ and $\mathrm{R}_{\mathrm{H} 2}$ ), the wastewater $\mathrm{C}_{\text {org }} / \mathrm{N}_{\mathrm{NO} 3}$ was at 0.47 . In the reactors with electrical current passage, the gas-
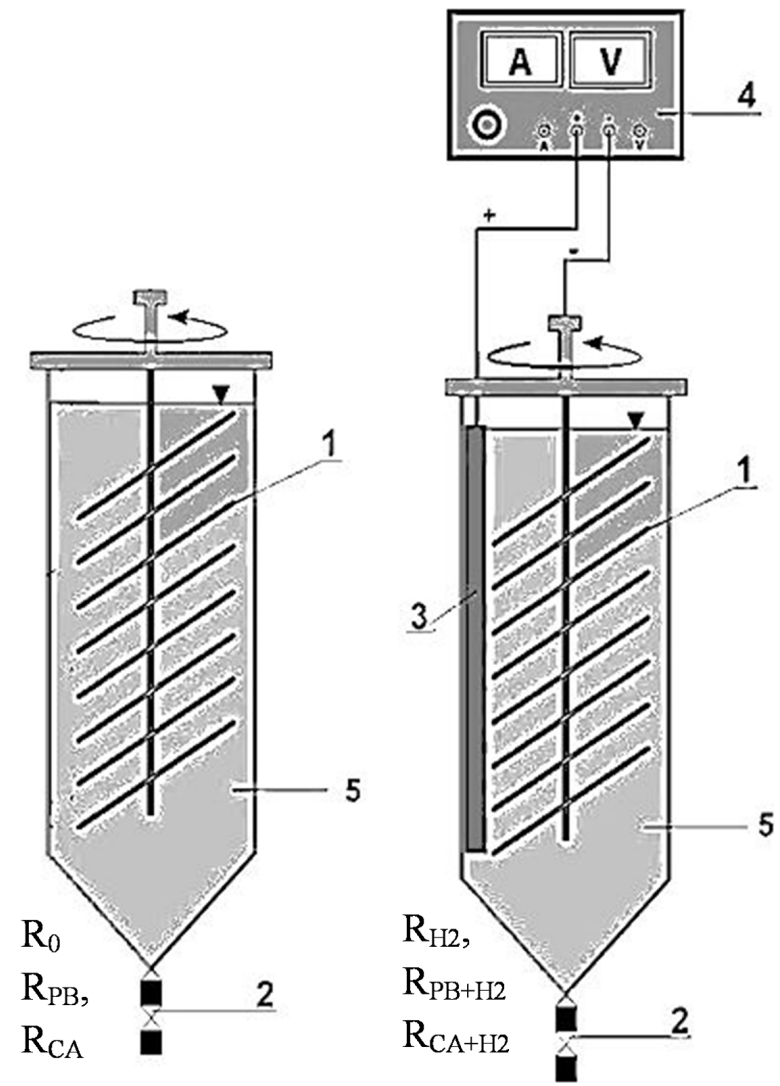

Fig. 1. Scheme of experimental model: (1) cathode discs with attached biofilm (stainless steel), (2) outlet, (3) anode (aluminum), (4) electric current source, (5) reactor 
eous hydrogen emitted from disks was the source of energy in the denitrification process. Hydraulic retention time was $24 \mathrm{~h}$ in each reactor. Before the exact experiment, the reactors were adapted for 3 months until appropriate structure of biofilm and stable concentration of nitrogen compounds in the effluent have been achieved.

In the reactors with electrical current passage, provided by laboratory feeders - Programmable DC Power Supply - HANTEK PPS 2116A $(0-5 \mathrm{~A})(0-32 \mathrm{~V})$ and MANSON DC Power Supply - DPD $3030(0-3 \mathrm{~A}, 0-30 \mathrm{~V})$, the disks with immobilized biofilm served as the cathode, whereas an aluminum plate with a total surface area of $0.033 \mathrm{~m}^{2}$ served as the anode. The cathode and the anode were connected to the laboratory feeder to ensure the desired density of electrical current, i.e. $53,105,158$ and $210 \mathrm{~mA} / \mathrm{m}^{2}$ (current intensity was $10,20,30$ and $40 \mathrm{~mA}$, current voltage ranged from 3.0 to $5.0 \mathrm{~V}$ ). The experiment was conducted for 16 weeks under the conditions of controlled $\mathrm{pH} 7.5-8.0$ (by $\mathrm{NaOH}$ or $\mathrm{HCl}$ application).

\section{WASTEWATER CHARACTERISTICS}

The experiments were conducted with synthetic wastewater with physicochemical parameters typical of municipal sewage subjected to bio-treatment in the system enabling highly efficient removal of organic compounds and highly efficient nitrification. Wastewater was characterized by high concentrations of nitrate nitrogen and total phosphorus, and by a low concentration of organic matter expressed by the COD value. In order to prepare the synthetic wastewater, the following compounds were dissolved in 2.0 $\mathrm{L}$ of tap water: $\mathrm{NaNO}_{3}, \mathrm{KH}_{2} \mathrm{PO}_{4}$ enriched broth $(0.08 \mathrm{~g} / \mathrm{L})$ BIOCORP PS $110, \mathrm{KCl}(0.021 \mathrm{~g} / \mathrm{L})$, $\mathrm{MgSO}_{4} \cdot 7 \mathrm{H}_{2} \mathrm{O}(0.308 \mathrm{~g} / \mathrm{L})$, and $\mathrm{CaCl}_{2}(0.021 \mathrm{~g} / \mathrm{L})$. Mean values of the physicochemical parameters of the crude wastewater were as follows:

- concentration of nitrate nitrogen - 50.68 $( \pm 1.61) \mathrm{mgN}_{\mathrm{NO} 3} / \mathrm{L}$,

- concentration of nitrite nitrogen - 0.0 $\mathrm{mgN}_{\mathrm{NO} 2} / \mathrm{L}$,

- concentration of ammonium nitrogen - 0.0 $\mathrm{mgN}_{\mathrm{NH} 4} / \mathrm{L}$,

- concentration of total phosphorus - 5.16 $( \pm 0.20) \mathrm{mgP} / \mathrm{L}$,

- concentration of $\mathrm{COD}_{\mathrm{Cr}}-70.30 \quad( \pm 10)$ $\mathrm{mgO}_{2} / \mathrm{L}$,

- electrolytic conductance $-1.74( \pm 0) \mathrm{mS} / \mathrm{cm}$,

- temperature $-25.3( \pm 0){ }^{\circ} \mathrm{C}$.

\section{Analytical methods}

The samples $(1.0 \mathrm{~L})$ were collected for analyses once a day. Afterwards, the reactors were emptied $(1.0 \mathrm{~L})$ and filled with wastewater $(2.0 \mathrm{~L})$.

The physicochemical analyses of crude and treated wastewater included determinations of:

- concentration of nitrate nitrogen with the colorimetric method [ISO 7890-3:1988],

- concentration of nitrite nitrogen with the colorimetric method [ISO 6777:1984],

- concentration of ammonium nitrogen with the colorimetric method [PN-C-04576/04:1994],

- concentration of total phosphorus with the spectrophotometric method based on the procedure developed by Lange LCK company,

- concentration of organic compounds (COD) with the spectrophotometric method based on the procedure developed by Lange LCK company,

- electrolytic conductance using an HI 99301 conductometer by Hanna Instruments,

- $\mathrm{pH}$ value using a laboratory $\mathrm{pH}$-meter PL $700 \mathrm{AL}$ type $\mathrm{pH}-\mathrm{mV}$-Cond-TDS-DO stirrer.

- temperature using a digital thermometer by JVTIA.

\section{RESULTS AND DISCUSSION}

In this study, we analyzed the effect of electrical current density, substrate type and $\mathrm{C} / \mathrm{N}_{\mathrm{NO} 3}$ value on the efficiency of nitrogen and phosphorus compounds removal in the bio-electrochemical SBBR.

The efficiency of denitrification in the reactor without the external source of carbon $\left(\mathrm{R}_{0}\right)$ reached $10.31( \pm 2.4) \%$. Feeding potassium bicarbonate to the reactor $\left(\mathrm{R}_{\mathrm{PB}}\right)$ enabled increasing it to: $43.67( \pm 1.8) \%, 13.46( \pm 1.56) \%$ and $15.04( \pm 0.8) \%$ at $\mathrm{C} / \mathrm{N}$ of $0.5,1.0$ and 1.5 , respectively, while feeding citric acid to the reactor led to its higher values, reaching $13.46( \pm 1.82) \%, 17.6( \pm 1.48) \%$ and $19.9( \pm 1.67) \%$ at $\mathrm{C} / \mathrm{N}$ of $0.5,1.0$ and 1.5 , respectively (fig. 2).

Under the conditions of passage of electrical current with density of $53 \mathrm{~mA} / \mathrm{m}^{2}$, the feeding of an external source of carbon caused an increase in denitrification efficiency compared to the $\mathrm{R}_{\mathrm{H} 2}$ reactor in which it reached $9.64( \pm 1.33) \%$.

Higher values of denitrification efficiency were achieved upon the use of citric acid, i.e. $48.89( \pm 1.47) \%, \quad 52.75( \pm 2.0) \%$ and $69.43( \pm 2.22) \%$ at $\mathrm{C} / \mathrm{N}$ of $0.5,1.0$ and 1.5 , re- 
spectively. In the reactors fed with potassium bicarbonate, the respective values were insignificantly lower and accounted for $44.16( \pm 2.33) \%$, $47.13( \pm 2.0) \%$ and $53.62( \pm 4.13) \%$ at $\mathrm{C} / \mathrm{N}$ of 0.5 , 1.0 and 1.5 respectively. Increasing the electrical current density to $105 \mathrm{~mA} / \mathrm{m}^{2}$ caused a further increase in the denitrification efficiency, which was insignificantly higher in the reactors with potassium bicarbonate: $82.25( \pm 4.67) \%, 84.47( \pm 2.01) \%$ and $85.54( \pm 2.25) \%$ at $\mathrm{C} / \mathrm{N}$ of $0.5,1.0$ and 1.5 , respectively, than in the reactors with citric acid: $79.4( \pm 1.2) \%, 81.93( \pm 1.46) \%$ and $82.5( \pm 1.47) \%$ at $\mathrm{C} / \mathrm{N}$ of $0.5,1.0$ and 1.5 , respectively.

In the $\mathrm{R}_{\mathrm{H} 2}$ reactor, the efficiency of nitrogen compounds removal reached 20.29 $\pm(3.15) \%$. Further increase of electrical current density to $158 \mathrm{~mA} / \mathrm{m}^{2}$ raised the efficiency of nitrogen compounds removal in the reactors with citric acid, the final values of which reached: $81.54( \pm 1.12) \%$, $83.03( \pm 3.52) \%$ and $83.34( \pm 5.2) \%$ at $\mathrm{C} / \mathrm{N}$ of 0.5 , 1.0 and 1.5 , respectively. In the case of feeding potassium bicarbonate, denitrification efficiency decreased to $74.52( \pm 1.57) \%, 78.11( \pm 1.59) \%$ and $80.07( \pm 0.7) \%$ at $\mathrm{C} / \mathrm{N}$ of $0.5,1.0$ and 1.5 , respectively, and higher concentrations of nitrites and ammonium nitrogen were determined in the effluent. Conducting the treatment process only under conditions of electrical current passage, without the external source of carbon being fed to the reactors, allowed obtaining $23.2( \pm 0.8) \%$ efficiency of the process. In turn, the use of electrical current with a density of $210 \mathrm{~mA} / \mathrm{m}^{2}$ increased the denitrification efficiency in the reactors with citric acid to: $83.05( \pm 1.16) \%, 85.87( \pm 2.82) \%$ and $87.61( \pm 1.6) \%$ at $\mathrm{C} / \mathrm{N}$ of $0.5,1.0$ and 1.5 , respectively. In the reactors with potassium bicarbonate used as the external source of carbon, the removal efficiency of nitrogen compounds was observed to further decrease while the concentrations of nitrites and ammonium nitrogen to increase in the effluent. The efficiency of denitrification obtained in these reactors reached $66.21( \pm 0.39) \%$, $57.35( \pm 0.75) \%$ and $55.11( \pm 2.84) \%$ at $\mathrm{C} / \mathrm{N}$ of 0.5 , 1.0 and 1.5 , respectively.

In the conducted experiment, the nitrogen compounds were removed mainly in the biological processes. As reported by Li et al. (2009), the electrochemical effect - namely the possibility of nitrogen removal in the process of electrochemical reduction on the surface of cathode - may be omitted at electrical current densities of 50-200 $\mathrm{mA} / \mathrm{m}^{2}$. Zhao et al. (2011) claim that the co-action of autotrophs and heterophytes may be beneficial compared to the autotrophic denitrification alone. The carbon dioxide produced during the heterotrophic denitrification may serve as an additional source of inorganic carbon to autotrophic bacteria (the so-called synergism). Lee et al. (2013) discovered the co-existence of denitrifying autotrophs and heterotrophs at $\mathrm{C} / \mathrm{N}=0.8$. In turn, Hao et al. (2013) reported the occurrence of both heterotrophic and autotrophic bacteria responsible for the nitrates removal in the reactor with even higher wastewater $\mathrm{C} / \mathrm{N}$, i.e. $\mathrm{C} / \mathrm{N}=1.5$. According to Zhao et al. (2011), an increase of $\mathrm{C} / \mathrm{N}>1.0$ enhances the growth of heterotrophs. Feeding organic substances to the bio-electrochemical system leads to the intensification of the denitrification process [Feng et al., 2013], which is confirmed by the results obtained in our study. Feeding of an external source of carbon in the form of citric acid increased the denitrification ef-

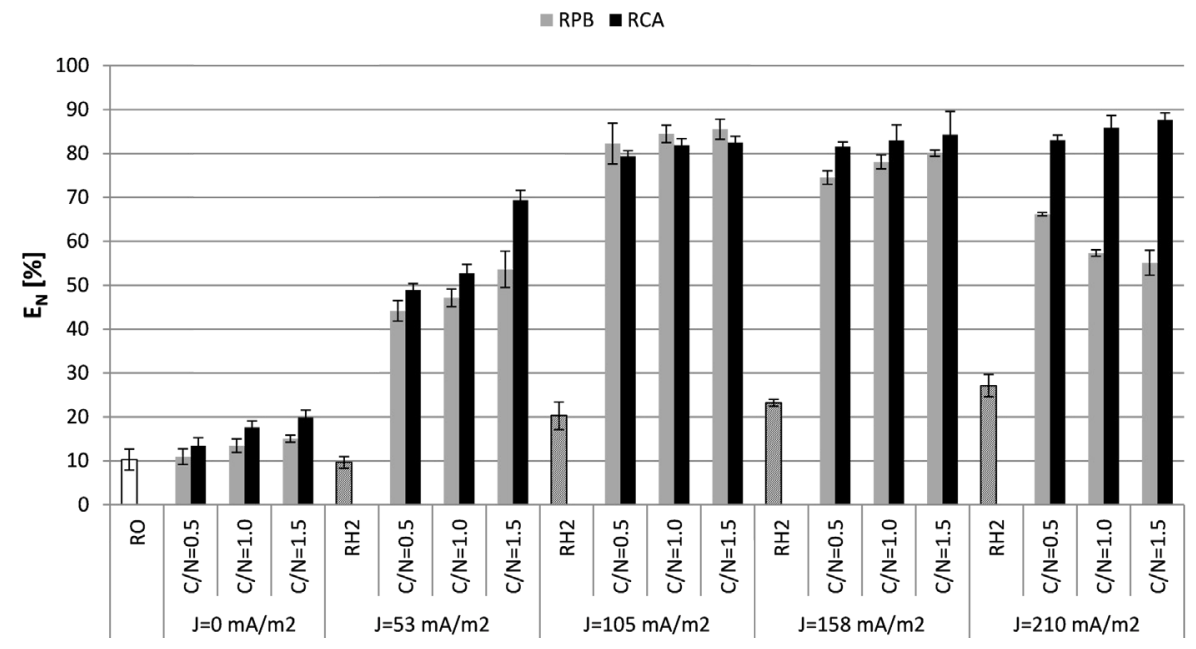

Fig. 2. The efficiency of nitrogen removal depending on electrical current density and $\mathrm{C} / \mathrm{N}_{\mathrm{NO} 3}$ ratio 
ficiency, which was further intensified by the use of a sufficiently high density of electrical current. The carbon source deficiency may be the major factor promoting accumulation of nitrites [Zhang et al., 2012]; hence, the electrical current densities applied for in-situ hydrogen production must be kept at an appropriate level. Both, too high and too low density of electrical current would cause nitrites accumulation [Islam and Suidan, 1998]. Tong et al. [2013] successively increased the current density to $200 \mathrm{~mA} / \mathrm{m}^{2}$ and obtained respectively lower concentrations of nitrates in wastewater. They managed to achieve the maximum efficiency of nitrates removal equal to $99.9 \%$. The use of electrical current with densities exceeding $200 \mathrm{~mA} / \mathrm{m}^{2}$, led to an increase in nitrates concentration. Raising the current density to $320 \mathrm{~mA} /$ $\mathrm{m}^{2}$ caused a rapid increase in their concentration, which resulted in reduced efficiency of nitrates removal [Tong et al., 2013]. The low density of electrical current does not ensure the sufficient hydrogen production, while its high density may inhibit the activity of microorganisms and even lead to their eradication [Flora et al., 1994].

The use of an inorganic source of carbon in the form of potassium bicarbonate at lower electrical current densities, i.e. 53 and $105 \mathrm{~mA} / \mathrm{m}^{2}$, contributed to an increase in the nitrogen compounds removal efficiency. Ghafari et al. [2009] demonstrated that - compared to carbon dioxide - bicarbonate caused accelerated adjustment of autotrophs and more abrupt growth of denitrifiers. However, the use of higher current densities $\left(158\right.$ and $\left.210 \mathrm{~mA} / \mathrm{m}^{2}\right)$ resulted in a decrease of nitrogen removal efficiency and an increase in the ammonium nitrogen concentration in the effluent. The accumulation of ammonium nitrogen in bioelectrochemical reactors may be caused by dissimilative reduction of nitrates to ammonium nitrogen (DNRA) [Zhang et al., 2012]. Zhao et al. [2012] came to the conclusion that ammonium nitrogen concentration decreased along with the decreasing $\mathrm{C} / \mathrm{N}$ ratio. Similar results were achieved by Zhang et al. [2012] during DNRA in bioelectrochemical systems, who reported that a higher $\mathrm{C} / \mathrm{N}$ value might lead to enhanced accumulation of ammonium nitrogen.

In this study, the phosphorus compounds were removed mainly in the electrocoagulation process. The dephosphatation efficiency in the reactor without the external source of carbon $\left(\mathrm{R}_{0}\right)$ reached $6.94( \pm 1.1) \%$. Feeding potassium bicarbonate caused no increase in its value which reached $6.05( \pm 1.5) \%, 6.24( \pm 0.85) \%$ and $6.84( \pm 0.47) \%$ at $\mathrm{C} / \mathrm{N}$ of $0.5,1.0$ and 1.5 , respectively. In the case of citric acid fed to the reactors as the source of carbon, the respective values were insignificantly higher and reached 7.12( \pm 0.9$) \%$, $8.03( \pm 0.79) \%$ and $9.04( \pm 0.51) \%$ at $\mathrm{C} / \mathrm{N}$ of 0.5 , 1.0 and 1.5 , respectively (Fig. 3).

Wastewater treatment under the conditions of electrical current passage contributed to an increase in the dephosphatation efficiency. Upon the use of electrical current with the density of $53 \mathrm{~mA} / \mathrm{m}^{2}$, the phosphorus removal efficiency in the $\mathrm{R}_{\mathrm{H} 2}$ reactor reached $71.01( \pm 1.4) \%$. Feeding external source of carbon to the reactors led to a further increase in the process efficiency, i.e. to $82.33( \pm 2.3) \%, 84.23( \pm 1.4) \%$ and $85.53( \pm 1.4) \%$ at $\mathrm{C} / \mathrm{N} 0.5,1.0$ and 1.5 , respectively, in the case of citric acid, and to insignificantly lower values of $81.96( \pm 3.6) \%, 83.13( \pm 2.8) \%$ and $84.05( \pm 2.3) \%$ at $\mathrm{C} / \mathrm{N} 0.5,1.0$ and 1.5 , respectively, in the case of potassium bicarbonate. Increasing the electrical current density to $105 \mathrm{~mA} / \mathrm{m}^{2}$ caused a further increase in the efficiency of phosphorus compounds removal. At this density, insignificantly higher efficiency values were also observed in the reactors fed with citric acid as the source of carbon, i.e. $89.23( \pm 2.9) \%, 92.31( \pm 1.8) \%$ and $92.88( \pm 1.18) \%$ at $\mathrm{C} / \mathrm{N} 0.5,1.0$ and 1.5 , respectively. In the case of potassium bicarbonate, the respective values were as follows: $85.24( \pm 4.4) \%$, $86.37( \pm 4.3) \%$ and $87.12( \pm 5.2) \%$ at $\mathrm{C} / \mathrm{N} 0.5,1.0$ and 1.5 , respectively.

Only slightly lower efficiency was achieved in the $\mathrm{R}_{\mathrm{H} 2}$ reactor $-82.8 \pm(2.01) \%$. The use of electrical current with the density of $158 \mathrm{~mA} / \mathrm{m}^{2}$ increased the dephosphatation efficiency in all treatment systems. In the reactors with citric acid fed as the external source of carbon, the process efficiency reached $92.31( \pm 4.35) \%, 93.54( \pm 3.2) \%$ and $95.34( \pm 2.8) \%$ at $\mathrm{C} / \mathrm{N} 0.5,1.0$ and 1.5 , respectively, whereas in the reactor with potassium bicarbonate it was insignificantly higher and reached $90.58( \pm 4.5) \%, 91.39( \pm 4.6) \%$ and $94.09( \pm 2.7) \%$ at $\mathrm{C} / \mathrm{N} 0.5,1.0$ and 1.5 , respectively. Conducting the treatment process only under the conditions of electrical current passage, without additional carbon feeding, enabled reaching the process efficiency of $84.2( \pm 1.68) \%$. The use of electrical current with a density of $210 \mathrm{~mA} / \mathrm{m}^{2}$ affected the successive increase in dephosphatation efficiency in all treatment systems, i.e. to $93.85( \pm 5.3) \%, 96.39( \pm 2.42) \%$ and $97.69( \pm 2.1) \%$ at $\mathrm{C} / \mathrm{N} 0.5,1.0$ and 1.5, respectively, in the case of 


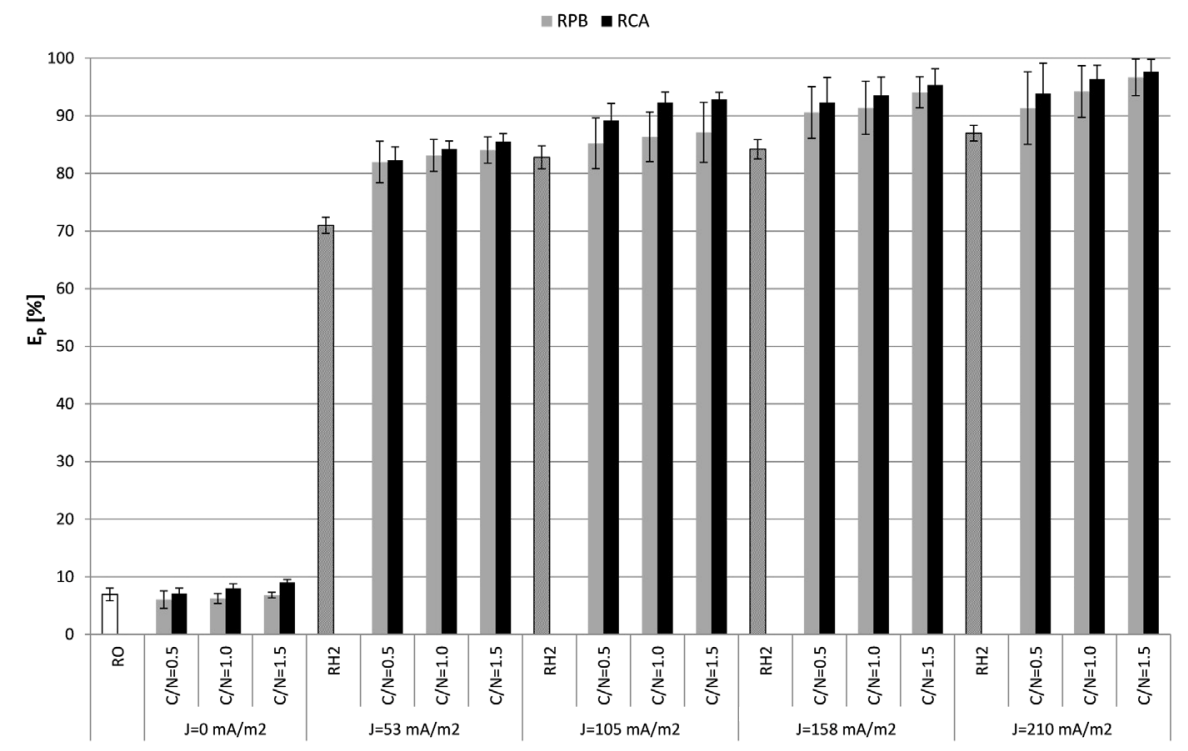

Fig. 3. The efficiency of phosphorus removal depending on the electrical current density and $\mathrm{C} / \mathrm{N}_{\mathrm{NO} 3}$ ratio

the reactors with citric acid, and to $91.35( \pm 6.3) \%$, $94.23( \pm 4.5) \%$ and $96.68( \pm 3.2) \%$ at $\mathrm{C} / \mathrm{N} 0.5,1.0$ and 1.5 , respectively, in the case of the reactors with potassium bicarbonate. In turn, the dephosphatation efficiency determined in the $\mathrm{RH}_{2}$ reactor reached $86.99( \pm 1.37) \%$.

The use of aluminum anode in the conducted experiment enabled simultaneous removal of phosphorus in the electrocoagulation process and in the process of biofilm growth. The effectiveness of dephosphatation depends on the quantity of aluminum being formed which is, in turn, affected by the reaction duration and electrical current density [Zaroual et al., 2006]. İrdemez et al. [2006] reported the aluminum electrode to be more suitable for dephosphatation conducted via the electrocoagulation method than the iron electrode, considering the rate and efficiency of phosphorus compounds removal. Behbahani et al. [2011] investigated the effect of the type of electrode on the dephosphatation efficiency and observed enhanced phosphorus removal along with increasing electrical current density for both aluminum and iron electrodes; however, obtained higher process efficiency in the case of the aluminum electrode. Besides, the use of the iron electrode led to greater turbidity of the solution being treated, compared to the aluminum electrode. The results of an experiment conducted by Lacasa et al. [2011b] demonstrated the efficiency of electrocoagulation with iron electrodes to be significantly affected by the density of electrical current and to increase considerably at its lower densities. In the case of the aluminum electrode, the current density had a lesser effect on electrocoagulation; a slight increase in its efficiency was only observed at lower current densities. Shalaby et al. [2014] obtained the phosphorus compounds removal efficiency from 85 to $95 \%$ by increasing electrical current density from 1.13 to $4.54 \mathrm{~mA} /$ $\mathrm{cm}^{2}$ (11.34-45.40 A/m²). However, they used higher electrical current density and shorter retention time than in our study. The electrical current passage through electrodes results in their dissolution and formation of $\mathrm{Al}^{3+}$ ions which bind with the $\mathrm{OH}^{-}$ions forming aluminum hydroxides which are responsible for the electrocoagulation efficiency. At higher intensities of electrical current, the number of $\mathrm{Al}^{3+}$ ions formed upon anode dissolution increases accordingly to the Faraday's law. This results in an increased quantity of aluminum hydroxide which adsorbs a greater part of phosphorus compounds onto its surface. Increasing the electrical current density above the optimal value does not enhance the efficiency of contaminants removal, even despite sufficient amount of metal hydroxide floccules for contaminants precipitation [Shalaby et al., 2014].

\section{CONCLUSIONS}

1. The efficiency of nitrogen and phosphorus compounds removal was the lowest in the $R_{0}$ reactor without external source of carbon and without electrical current passage.

2. Feeding potassium bicarbonate and citric acid to reactors under the conditions of electrical 
current passage contributed to a significant increase in the denitrification efficiency.

3. Citric acid turned out to be a better source of carbon in the process of nitrogen compounds removal.

4. Feeding organic carbon to reactors enabled the removal of nitrogen compounds in a simultaneous process of heterotrophic and autotrophic denitrification with gaseous hydrogen - produced in the electrolysis process - as a source of energy.

5. Compounds of phosphorus were removed in the processes of electrocoagulation and biofilm growth. The highest efficiency of dephosphatation was achieved under the conditions of electrical current passage and citric acid dosage.

6 . The use of electrical current with a density of $210 \mathrm{~mA} / \mathrm{m}^{2}$ and citric acid as a source of carbon with $\mathrm{C} / \mathrm{N}=1.5$, allowed achieving $87.61( \pm 1.6) \%$ efficiency of denitrification and $97.69( \pm 2.1) \%$ efficiency of dephosphatation.

\section{Acknowledgments}

This study was financed under Project No. 18.610.008-300 of the University of Warmia and Mazury in Olsztyn, Poland. The project was also funded by the National Science Centre, Poland (the decision nr DEC-2013/09/N/ST8/04163).

\section{REFERENCES}

1. Behbahani M., Alavi Moghaddam M. R., Arami M. 2011. A comparison between aluminum and iron electrodes on removal of phosphate from aqueous solutions by electrocoagulation process. Int. J. Environ. Res., 5, 403-412.

2. Carrera J., Vicent T., Lafuente J. 2004. Effect of influent $\mathrm{COD} / \mathrm{N}$ ratio on biological nitrogen removal (BNR) from high-strength ammonium industrial wastewater. Process Biochem., 39, 2035-2041.

3. Feng H., Huang B., Zou Y., Li N., Wang M., Yin J., Cong Y., Shen D. 2013. The effect of carbon sources on nitrogen removal performance in bioelectrochemical systems. Bioresource Technol., 128, 565-570.

4. Flora J.R.V., Suidan M.T., Islam S., Biswas P., Sakakibara Y. 1994. Numerical modeling of a biofilm-electrode reactor used for enhanced denitrification. Water Sci. Technol., 29, 517 - 524.

5. Ghafari S., Hasan M., Aroua M.K. 2008. Bio-electrochemical removal of nitrate from water and wastewater - a review. Bioresour. Technol., 99, 3965-3974.
6. Ghafari S., Hasan M., Aroua M.K. 2009. Effect of carbon dioxide and bicarbonate as inorganic carbon sources on growth and adaptation of autohydrogenotrophic denitrifying bacteria. J. Hazard. Mater., 162, 1507-1513.

7. Hao R.X., Li S.M., Li J.B., Meng C.C. 2013. Denitrification of simulated municipal wastewater treatment plant effluent using a three-dimensional biofilm-electrode reactor: operating performance and bacterial community. Bioresour. Technol., 143, 178-186.

8. Hiscock K.M., Lloyd J.W., Lerner D.N. 1991. Review of natural and artificial denitrification of groundwater. Water Res., 25, 1099-1111.

9. Islam S., Suidan M.T. 1998. Electrolytic denitrification: long term performance and effect of current intensity. Water Res., 32, 528-536

10. İrdemez Ş., Yildiz Y. Ş., Tosunoğlu V. 2006. Optimization of phosphate removal from wastewater by electrocoagulation with aluminum plate electrodes. Sep. Purif. Technol., 52(2), 394-401.

11. Karanasios K.A., Vasiliadou I.A., Pavlou S., Vayenas D.V. 2010. Hydrogenotrophic denitrification of potable water: a review. J. Hazard. Mater., 180(1-3), 20-37.

12. Kłodowska I., Rodziewicz J., Janczukowicz W. 2014. Removal of nitrogen compounds in the process of autotrophic denitrification in a Sequencing Batch Biofilm Reactor (SBBR). Polish J. Nat. Sci., 29 (4), 359-369.

13. Kłodowska I., Rodziewicz J., Janczukowicz W., Cydzik-Kwiatkowska A., Parszuto K. 2016. Effect of citric acid on the efficiency of the removal of nitrogen and phosphorus compounds during simultaneous heterotrophic-autotrophic denitrification (HAD) and electrocoagulation. Ecol. Eng., 95, 30-35.

14. Kłodowska I., Rodziewicz J., Janczukowicz W., Filipkowska U. 2013. Effect of electrochemical process on the outflow from the reactor with immobilized biofilm (in Polish). Annual Set The Environment Protection., 15, 1952-1964

15. Kuokkanen V., Kuokkanen T., Rämö J., Lassi U., Roininen J. 2015. Removal of phosphate from wastewaters for further utilization using electrocoagulation with hybrid electrodes - Techno-economic studies. J. Water Process Eng., 8, 50-57.

16. Lacasa E., Cañizares P., Sáez C., Fernandez F.J. Rodrigo M.A. 2011. Electrochemical phosphates removal using iron and aluminium electrodes. Chem. Eng. J., 172, 137-143.

17. Lee S., Maken S., Jang J.-H., Park K., Park J.-W. 2006. Development of physicochemical nitrogen removal process for high strength industrial wastewater. Water Res. 40, 975-980.

18. Lee D.J., Pan X., Wang A., Ho K.L. 2013. Facul- 
tative autotrophic in denitrifying sulfide removal granules. Bioresour. Technol., 132, 356-360.

19. Li M., Feng C.P., Zhang Z.N., Lei X.H., Chen R.Z., Yang Y.N., Sugiura N. 2009. Simultaneous reduction of nitrate and oxidation by-products using electrochemical method. J. Hazard. Mater., 171, 724-730.

20. Shalaby A., Nassef E., Mubark A., Hussein M. 2014. Phosphate removal from wastewater by electrocoagulation using aluminium electrodes. Am. J. Environ. Eng. Sci., 1(5), 90 - 98.

21. Tong S., Zhang B., Feng C., Zhao Y., Chen N., Hao C., Pu J., Zhao L. 2013. Characteristics of heterotrophic/biofilm-electrode autotrophic denitrification for nitrate removal from groundwater. Bioresour. Technol., 148, 121-127.

22. Zaroual Z., Azzi M., Saib N., Chainet E. 2006. Contribution to the study of electrocoagulation mechanism in basic textile effluent. J. Hazard. Ma- ter., 131, 73-78.

23. Zhang J.M., Feng C.P., Hong S.Q., Hao H.L., Yang Y.N. 2012. Behavior of solid carbon sources for biological denitrification in groundwater remediation. Water Sci. Technol., 65(9), 1696-1704.

24. Zhao Y., Feng C., Wang Q., Yang Y., Zhang Z., Sugiura N. 2011. Nitrate removal from groundwater by cooperating heterotrophic with autotrophic denitrification in a biofilm-electrode reactor. J. Hazard. Mater., 192(3), 1033-1039.

25. Zhu S., Chen S. 2002. The impact of temperature on nitrification rate in fixed film biofilters. Aquacult. Eng., 26, 221-237.

26. Zhao Y.X., Zhang B.G., Feng C.P., Huang F.Y., Zhang P., Zhang Z.Y., Yang Y.N., Sugiura N. 2012. Behavior of autotrophic denitrification and heterotrophic denitrification in an intensified biofilm-electrode reactor for nitrate contaminated drinking water treatment. Bioresour. Technol., 107, 159-165. 